Bryn Mawr College

Scholarship, Research, and Creative Work at Bryn Mawr College

Anthropology Faculty Research and Scholarship

Anthropology

2018

\title{
Vision, Voice, and Cinematic Presence
}

Constantine V. Nakassis

Amanda Weidman

Bryn Mawr College, aweidman@brynmawr.edu

Let us know how access to this document benefits you.

Follow this and additional works at: https://repository.brynmawr.edu/anth_pubs

Part of the Anthropology Commons

\section{Citation}

Nakassis, Constantine V. and Amanda Weidman. 2018. "Vision, Voice, and Cinematic Presence." differences 29.3: 107-136.

This paper is posted at Scholarship, Research, and Creative Work at Bryn Mawr College. https://repository.brynmawr.edu/anth_pubs/13

For more information, please contact repository@brynmawr.edu. 
$\langle$ sc $>$ constantine v. nakassis $</$ sc $>$ and $\langle$ sc $>$ amanda weidman $</$ sc $>$

\section{Vision, Voice, and Cinematic Presence}

\section{<A>Image 1: An Image That Couldn't Be}

On a hot April afternoon in 2009 in a small rural village in southern Tamil Nadu, India, the film crew with whom Costas (Nakassis) was working on the Tamil film Goa (2010, dir. Venkat Prabhu) was milling about, waiting for the next shot to begin. The assistant directors were looking for a couple of extras for the shot. The scene needed village women, so they asked the woman whose house they were using for one of the indoor locations if she would like to act. She was in her early thirties, married with two small children. Her face betrayed interest, though she was reticent and equivocated. Her husband, who came a couple of minutes later, spoke in her stead: no, she wouldn't be acting. The assistant directors, all men, seemed to understand immediately and dropped the issue, wandering off to find someone else. Costas persisted, though, and asked him, why not let her act? The husband responded tersely, motioning to the dubious moral standing of the Tamil film industry. Thinking he was talking about stereotypes about casting couches (rumors of which have long been a source of stigma for women in the industry), Costas countered that he, the husband, would be there the whole time and would know that nothing wrong would have happened. The husband responded, as if to indicate that Costas misunderstood him: it wasn't proper because she would be seen onscreen, that is, seen by anonymous and unknown others in the dark expanse of the theater. That she could be seen 
onscreen, in public, was enough to trigger local gossip that would impugn not just her but his honor as well. For her to be seen, for an image of her to appear, was itself an act--an act that couldn't come to pass, an image that wouldn't be.

\section{<A>Image 2: An Invisible Audible Voice}

Mallika Sherawat is dancing to a heavily saturated audio track, her thin, fair body surrounded by a visually lavish set in the 2011 film Osthi (dir. Dharani). Formations of male and female dancers move in sync with her, gyrating their hips and shaking their chests. Mallika has already introduced herself as Mallika (her offscreen, personal name) in a thinly disguised description of transgressive sexual pleasure, inviting any who might dare to try her. She doesn't sing in her own voice, however, but in a voice provided by the elderly Tamil playback singer L. R. Eswari. As the verse finishes, the villain approaches, clumsily inserting himself into the dance and singing to Mallika in a high-pitched, metallic voice, only to have his fantasy interrupted by the hero (played by the actor T. R. Silambarasan, or Simbu as he is more commonly called), who announces his own arrival--“'Osthi tān vantirukkān!” (“Osthi has arrived!”)--and strides forward to take center stage. He tosses away a beer bottle as he begins an acrobatic show of dancing prowess, pushing the villain off to the side and twirling Mallika on his arm and then under his leg. The thick soundtrack disappears for these few moments, replaced by a curious sound--heavy breathing, almost like the sound of a saw cutting wood--accompanied only by the hollow beat of snare drums. The sound is not quite identifiable. It is neither anchored to the screen nor to the body of the dancer, who is seen running back and forth across the frame as it occurs. It is also 
disjointed from the voice of the playback singer herself. Here, the voice is reduced to its amusical substratum, breath, separated not just from the image but, for a moment, from itself.

\section{$<2$ II $>$}

These two vignettes describe the fate of two image-acts in Tamil cinema, one of appearance, the other of phonation. ${ }^{1}$ Each act has been forestalled in some capacity: either blocked before it could be fully captured and presenced onscreen or delinked from the visual text with which it co-occurs and from the identifiable singing voice that emitted it.

As we show in this paper, governing the fate of these images are particular anxieties (and desires) about presence: about the ways in which the offscreen personages of images' animators dwell in those very images, potentially implicating them in every event of their appearance/audition. In a cultural context like that of Tamil Nadu, where respectable femininity is defined by the careful management, and often avoidance, of public appearance, such moments of publicity are highly charged, performatively potent in ways that are as threatening as they are potentially exciting.

This potency organizes the production and reception of film in Tamil Nadu. While soundand image-tracks have always been separable (Chion, Audio-Vision), different cinematic traditions have reacted to this fact in different ways. Classic Hollywood cinema has denied the fragmentation of body and voice engendered by sound cinema, disavowing the fact that the matching of visual image with soundtrack is technologically constructed, and instead presenting

it as natural, as Mary Ann Doane famously argued in her essay "The Voice in Cinema.” By 
contrast, contemporary Tamil cinema has embraced this fragmentation--through distinguishable personnel and production processes for acting, speaking, dancing, and singing--as a positive condition that needs to be maintained, particularly for women. ${ }^{2}$ Thus, the onscreen bodies of actresses are de-voiced even as they are made visible, their speaking and singing voices often provided by dubbing artists and playback singers, women whose voices are dis-appeared, kept behind the veil of the screen.

Theorizations of gaze and voice in Euro-American film theory have reflected on the anxieties, and concomitant power dynamics, that swirl around the female form and voice. Laura Mulvey and Mary Ann Doane, in their classic pieces on the gaze as a tactic for objectifying the narratively excessive female body, and Kaja Silverman and Amy Lawrence, in their illustration of the ways in which the female voice is denied discursive mastery, present powerful critiques of the gendered power dynamics of filmic representations in classic Hollywood cinema. In this paper, we extend these critiques by pushing on what subtends the problem of representing the female form in Tamil cinema (and more generally, we would suggest): namely, the problem of presence.

Where we differ from the above critiques, however, is with regard to the presumption that narrative cinema is primarily a mode of representation, a textual array depicting a fictive, diegetic world that provides spectators with moments to look or hear. ${ }^{3}$ Such a semiotic ideology overlooks the possibility that the events that happen onscreen constitute acts in themselves, ${ }^{4}$ image-acts that while representational are also not only, or even primarily, representations. ${ }^{5}$ As a result, the tendency in much film studies has been to proceed as if filmic images are sui generis objects, texts autonomous from their animators, producers, and audiences, cordoned off by a fourth wall that extends all the way to the theater of film analysis itself. 
Here, we propose a different conceptualization of the cinematic image. The anxieties about presenting and presencing the female body and voice that are at work in Tamil cinema force us to contend with something at play for all filmic images, not just those of Tamil cinema, something that strains the very idea of cinema as representation. The semiotic ideology that governs the cases with which we opened this paper takes filmic images to be not (or not only) representations, but the relay of acts, and thus themselves performative acts in their context of occurrence and beyond. These are images that, in their enactment by the actress/dancer and dubbing artist/playback singer, become morally charged acts. Disseminated publicly through the cinema, such image-acts presence their animators' identities and thus, for better or worse, return to their offscreen persons. Further, such acts implicate not just the actress or singer but also the audience and wider film publics, for whom seeing and hearing such an image is also an act with moral consequences.

In what follows, we explore the vision-image and the sound-image as two linked but distinct producers and mediators of presence, noting the division of semiotic labor between appearing and sounding, but also their interaction and interdependence. As we show, their entangled performativities leave traces both on and off the screen, in/as the film text and in/as the personages of the film image's animators.

\section{$<\mathrm{A}>$ Vision-Image}

The ongoing importance of Mulvey's essay "Visual Pleasure and Narrative Cinema" lies in its insistence on a widespread patriarchal economy of images, and further, in its specification of a semiotic form--structures of looking intercalated with narrativized images of female 
spectacle--that manifests this economy. Even in film cultures that do not conform to the dynamics of classic Hollywood cinema with which Mulvey is concerned in her essay, such as the Tamil film industry, we can find analogous if never identical looking structures (Nair; Vardhan).

Consider again the song-and-dance sequence discussed above, "Kalasala Kalasala" from Osthi, which occurs about two-thirds of the way through the film. The previous scene narratively sets up the sequence by showing how the villain, "Boxer" Daniel (who runs a local alcohol brand), "has arranged for a girl who is hot like Boxer rum" ("Boxer rum mātiri gummu nnu oru poṇnu êrpāṭu pannirukkār-rā”’) to entertain him and his henchmen. We hear this line voiced by one of his men as we see a tight close-up of two bottles of rum. Daniel pulls the bottles apart to reveal his grinning, sunglass bespectacled face. The camera zooms out and we see him circled by his henchmen, eager to consume the alcohol (and the girl). There is a cut, and the song begins with a series of briskly edited shots.

We first hear a female voice, singing a wordless melody over drums and a dark, ethereal synthesizer. Cut to a close-up of a woman's bare feet adorned with golden anklets. She is standing on her right foot, her left foot raised in the air, her toes tapping downward on the downbeat of the music as the camera zooms in on her ankles. There are women's hands with matching gold bangles waving up and down. The shot cuts back to a high-angle long shot revealing the dramatically lit space. In the center is a stage, in the middle of which is the dancer, Mallika, with her back to us. She is wearing a revealing open-back crop top and a choli skirt. The camera gives us numerous shots of her hips and back (but not her face), her body gyrating to and fro, until finally it cuts to a medium shot that shows her turning around. Before the camera shows us her face, however, there is a cut to the villain and his henchmen. The villain bunches his fingers, touching their tips to his lips; he turns to the camera (and presumably to Mallika), 
throwing a kiss in a frontal shot. The camera then cuts back to an image that the previous shots of Mallika promised: a frontal view of her body in which we see her breasts and her stomach (but not her legs or head), her hands on her hips, turning in a circular motion. It then cuts to a medium-close shot of Mallika's shoulders and her face, finally revealed to us as she faces us/the camera directly, her head slightly cocked, eyes locked on us/the camera. She bites her lip as her shoulders snake up and down, back and forth. With this, the song's intro gives way to its chorus as the dancers engage in a tightly choreographed dance sequence in a frontal presentation to the camera.

The "looks" of this sequence offer clear examples of the kinds of relays that Mulvey describes in terms of "fetishistic voyeurism": shots of the female body alternating with shots of the villain (and later the hero) ogling her, offering the spectator a set of sites for identifying with the gaze of the apparatus as it apprehends her body. But in addition to this, we also have a surfeit of shots of Mallika, as well as of the villain and later the hero, looking directly at the camera. Almost three minutes into the song, after the hero, Osthi, has arrived, there is a medium-close shot of Osthi/Simbu looking directly at Mallika (while the male background dancers similarly ogle her) as Mallika looks directly at the camera. The camera pans down as Osthi/Simbu slides his body down hers, putting his hands on her hips and shaking his head near her stomach in tandem with her hips. Here Osthi/Simbu is looking directly at the camera, reversing the looking scheme: from Osthi/Simbu looking at Mallika looking at us, now to Osthi/Simbu looking at us as Mallika's look has been erased. Osthi/Simbu then turns his gaze to look and point directly at Mallika's stomach as he sings. Mallika drops down and Osthi/Simbu's head raises up to her breast and then to her face. They look at each other. Osthi/Simbu looks away from the camera as Mallika looks at the camera, allowing Osthi/Simbu's look to be displaced so that another gaze 
can be opened: that of Mallika seeing and being seen (as seeing) by us and us alone. Mallika then leans back, her gaze turned away from the camera as Osthi/Simbu lays his head on her breast, looking up at her and smiling contently.

In sequences such as this, and throughout the song, Mallika repeatedly looks at the camera and winks, at times amplifying and at times bypassing the relay of looks that positions the spectator as voyeur. Such looks at the camera are sometimes set up by previous shots of the villain or hero ogling Mallika, such that the cut to the look of her gazing at the camera is ambiguously a look at the hero/villain and the audience; but they are just as often not and are thus unmotivated by anything but the direct address of Mallika's gaze at the viewer.

Here we have multiple image-orientations at play, some of which present themselves as self-contained and external to the spectator/voyeur (Mulvey, "Visual" 17) and some of which break the so-called fourth wall and presence themselves in the moment of the image's appearance to its viewer/addressee (Willemen). The latter constitute a full-tilt, frontal aesthetics, an exhibitionism that presumes the copresence of the actress with the audience. Such a deictic orientation of the screen image (Casetti) is highly conventionalized for Indian cinemas (Vasudevan). ${ }^{6}$

"Kalasala Kalasala" is what is called in Indian cinemas an "item number." Item numbers are stand-alone song-and-dance sequences, both in the sense that they are shot on their own schedule but also in that they are narratively detached from the rest of the film, often simply dropped in at moments in the film as "interruptions" of the narrative, as Lalitha Gopalan has noted. Such song-and-dance sequences feature dancers (that is, "items") who are often not characters and who, if identified, are often identified by their offscreen names, as with Mallika. 
As exasperated critics often note, item numbers exist to crassly titillate; they are vulgar strip teases that simply satisfy a male desire (that of the hero, filmmaker, audience) to see the female body. $^{7}$

As Mulvey notes, while most Hollywood narrative cinema integrates the spectacle of the female form within its narrative, "[M]usical song-and-dance numbers interrupt the flow of the diegesis," opening up a spacetime of exception to the narrative dynamics that concern her essay ("Visual" 19-20). And indeed, the duality of looking structures noted above--a regime of voyeurism and of exhibitionism, of identification and of direct address--is reflected in the loose integration of this sequence to the narrative. ${ }^{8}$ While the "Kalasala Kalasala" sequence puts on display the villain's moral corruption and stages the antagonism between the villain and the hero, who has arrived to "raid" the villain's party (while demonstrating his sway over Mallika's affections), it has no necessary narrative function. Instead, it fulfills a genre convention, itself understood by audiences to be a break from the narrative.

The item number, in short, is only partially articulated to the larger narrative. Facing both inward to the diegesis and outward to the audience, it is a kind of contact zone that embodies a particular tension suffusing Tamil films, and perhaps narrative cinema more generally. This tension has been variously captioned in film theory with binaries like narrative/spectacle (Mulvey, "Visual"), language/ontology (Bazin), and classical/primitive (Gunning; Hansen 24), among others.

The item girl functions specifically as what Mulvey terms "spectacle," that which is "excessive" of the narrative: the "to-be-looked-at-ness" of the female form that stills the forward linear progression of the narrative's (masculine) chronotope. Mulvey writes, "The presence of 
woman is an indispensable element of spectacle in normal narrative film, yet her visual presence tends to work against the development of a storyline, to freeze the flow of action in moments of erotic contemplation. This alien presence then has to be integrated into cohesion with the narrative." Later in the same essay, she writes of the "showgirl" whose dance has been integrated into the diegesis (as, for example, in $O s t h i)$ : "For a moment the sexual impact of the performing woman takes the film into a no man's land outside of its own time and space [...]. Similarly, conventional close-ups [. . . ] integrate into the narrative a different mode of eroticism. One part of a fragmented body destroys the Renaissance space, the illusion of depth demanded by the narrative; it gives flatness, the quality of a cut-out or icon, rather than verisimilitude, to the screen" (20). Here, Mulvey makes two important observations: first, that the erotic image of the dancer exceeds and thus stands in tension with the narrative, working on it, interrupting and stilling it through the "impact of the performing woman" and her "alien presence" (and not her representational image); and second, that this exhibitionist addressivity has an aesthetic flatness. While Mulvey characterizes this flatness as lacking depth--vis-à-vis the side of the screen that spills into the diegetic world (that which is "behind" it, as it were)--this "flatness" is, we suggest, also a spatiotemporal extension into the world of the theater, that is, into the displaced time and space of the image as it impacts in the event of her appearance (see Mulvey, "Thoughts" 215). This is a forward-facing depth. It is a presencing of the actress to her audiences. The "impact" of the performing woman lands not just outside of the spacetime of the diegesis but outside of the film text itself.

The (extra)textual curation of "Kalasala Kalasala" abets this act of presencing. Mallika is centered on the screen, the object of the camera's scrutiny. Her presence is also linguistically foregrounded: as we gaze upon her gazing upon us, Mallika is referred to and addressed in a 
song about her as Mallika. ${ }^{9}$ In these ways, this sequence adulates Mallika, providing her a stage from which to be seen and taken in for who she is: a star actress. And indeed, rather than being the hero's or the director's song (as we might say of the rest of the film text), this is Mallika's song. Mallika Sherawat is a well-known Bollywood celebrity, and her presence in Osthi was in itself a source of "value" adding to the film's commercial equation. It was reported in industry publications that she had signed the film for 12 million rupees (in 2011, around $\$ 233,000$; this out of an estimated film budget of 300 million rupees) for a two-to-three day shoot ("Mallika").

But critical for us is that more than simply being a vehicle for Mallika Sherawat or just another spectacle attraction for this would-be blockbuster; more than just a set of patriarchal looks; more than a representation of sexuality that is sexual, for Tamil film audiences such a representation is also a morally charged act, one that redounds back to Mallika herself.

It is on this point that we can expand on Mulvey and other feminist film theorists. Moving beyond their concern with the screen text and its reception, we can note with Paul Willemen (107) that the interrupting act of appearance, rather than simply arresting the look of the (text-internal, and thus decontextualizable) spectator, is a performative act that engages the look of an embodied viewer in a specific context (including, but not limited to that of the theater $)^{10}$ embedded within a wider public sphere. ${ }^{11}$ That is, these dynamics traverse the screen and generate performative (and textual) effects that cannot be fully captured by a narrow textfocal analysis.

Such performative effects adhere to the object of that very look, requiring not only textual and narrative but also offscreen "solutions" to the problem of female presence. What Mulvey calls "sadistic scopophilia" doesn't just happen in a film's story; it also works in the 
event of (theatrical) appearance and beyond, for example, in forms of stigma that have historically been attached to film actresses in Tamil Nadu by virtue of their onscreen appearances. ${ }^{12}$ How, then, might we reconstruct not the textual or technological but the "social apparatus," as Linda Williams (45) has called it, of this performativity, this image-act of appearance and presence?

\section{$<\mathrm{A}>$ To Sight an Item}

To appear in a film world (as a representation) is to appear on the screen, and to be present, in some sense, in the theater. This tautology implies something often glossed over in our quick movement to emphasize the representationality of the image, something profound, if equally tautologous: to act (and to appear onscreen while doing so) is itself an action, an act (Saltz). How this fact is variously elaborated in different screen cultures is important. In the Tamil case, for a young woman to appear onscreen, and therefore in public, is a morally charged act unto itself.

This is so for a number of reasons. In Tamil Nadu, as in much of South Asia, norms of respectability for men and women revolve around the control of how and when they inhabit public space, how and when their appearance is available to others. In contrast to a man, however, by inhabiting public space, a woman always risks being sexualized. This sexualization consists in being available to be seen by onlooking men (the dynamics of which are deeply inflected by politics of caste, age, and class), and in becoming the object of gossip and innuendo. 
This sexualization is abetted by an insistent, conservative stereotype (one that is not historically unique to South Asia, of course), namely, that actresses are fallen women, or “prostitutes" as actresses are often dismissed today (Chinniah 40-41; Ganti 94; Hardgrave 95; Seizer). This stereotype is linked to the fact that in the early decades of Tamil cinema most actresses came from so-called Devadasi (or temple-dancer) communities, who through reformist movements of the nineteenth century were rebranded as prostitutes and relegated to the margins of respectability and community (Ramamurthy; Soneji). This history, combined with pervasive assumptions about casting couches and the like, makes cinema--among the various modes of public appearance--a particularly problematic site of presence. It seemed self-evident to many of our informants (young men in particular) that to be a film actress meant, as one young man put it, "lying down" (with the hero, director, or producer). Through a kind of ideological loop, the proof of this immorality for many was the actress's very appearance onscreen. Recall that it was this concern that motivated the husband's blockage of his wife's appearance onscreen at the Goa film shoot. As one relatively but not uncommonly conservative middle-class couple put it to Costas in Tamil, "What kind of family girl [kutumba poṇnu] would allow herself to be seen by anyone onscreen, hugging, kissing, bearing flesh?”

Here, the image is taken to index (and thus "prove") a fundamental corruptibility: the willingness to be seen. This appearance takes place within an imagination of theatrical reception. In asking, "what kind of family girl would choose to let herself be seen by anyone?" the couple above implicitly invoked an imagined crowd to which the actress gives herself over: low-caste, low-class men--"the incontinent spectators" or "pissing men" of the censor's imaginary (Mazzarella; Mazzarella and Kaur)--cloaked in the darkness of the public cinema hall, ogling, but also hooting, hollering, and whistling (all activities that typically accompany the appearance 
of a particularly erotic female image). This sexualized form of public vision is denoted in Tamil slang by the code-mixed phrase "sight ațikkiratu," literally "beating sight," an assault of the eyes on its object of vision.

While this look might be taken as conforming to the cinematic gaze described in feminist critiques of Euro-American cinema (and visual media more generally), at issue here is not just the sexual objectification of the gaze. Rather, it is a scene (or chronotope) of vision, one that implicates not just a spectator subject and a seen object but an embodied male viewer who stands in a set of relationalities with the screen (expressed through intent vision and intense whistling, hooting, and hollering), with other viewers (homosocial male peer groups with whom one ogles in the public space of the theater; offended others who object to such vulgarities; embarrassed family members that one is caught watching with; and so on), and with the actress herself (variously characterized by male viewers as a kanavu kanni [“dream girl/virgin”] or a prostitute) as seen through her character.

The absent anchor of this scene of vision is the kin unit (ideologies about which emanate from upper-caste, middle-class formations)--hence the key ideological signifier, "family," in the phrase "family girl" (kutumba poṇnu) noted above. In contrast to the open publicity of the cinema hall, the kin group is the moral center of respectable (non)appearance and vision and a unit of sexual surveillance and regimentation, a shield that stands between flesh and flesh, and the image thereof. By contrast, the image that is offered up to be sight ați-ed figures its object as unrelated, as non-kin. Marriage is a ritual transformation that makes actresses, based on public norms of propriety, unavailable or only embarrassingly available for sight ațikkiratu. As a lowermiddle-class informant in Chennai ambivalently explained in Tamil, women acting is fine, as long as they aren't kin, as long as they aren't "our girls." "It's like sight ați-ing girls (in public 
places)--when they aren't our sisters or mothers, we enjoy it. But if others are looking at them like that, we get upset." By this logic, in order to be sight-ed the actress must be not "ours"; she must be unrelated, sexually available, and perhaps even non-Tamil. And indeed, it has long been the case--and since liberalization, even more so--that actresses who play the heroine in commercial Tamil films are unmarried and non-ethnolinguistically Tamil (Nakassis, "Tamilspeaking").

But if the screen opens up a risky space of presence where the actress is rendered morally responsible for her appearance beyond the narrative representationality of the image, the stigma of the screen and the kinship logics of sight ațikkiratu are also mediated, and thus potentially mitigated, by that very representationality. Emphasizing the representationality of the image is itself a strategy for managing a male gaze that insists on seeing beyond the character, the story, the diegesis to directly apprehend the actress as a sexualized body. Indeed, not all women who appear onscreen are figured by the films in which they act as objects of sight. It is this fact that explains a common career pattern of heroine-actresses after marriage: ${ }^{13}$ switching to character roles in elder kin-relations to the hero, acting as older sisters, sisters-in-law, mothers, aunts, or grandmothers to the hero (even with the same heroes they once romanced onscreen), and thus sequestered from romantic scenes and from item numbers. Here, the narrative text, as a representation of a fictive world, veils the actress, obscuring her body through her character.

Mitigating the presence of the screen, however, does not only take place onscreen. Much image work must also be done offscreen by actresses--especially those who play heroines--to disassociate themselves from and disavow their appearances onscreen, to insert a gap between the screen and their selves, defeasing the performativity of their image and rendering it merely a representation not of them, but of some character. Widely circulated stories--such as the 
legendary heroine Saroja Devi's (b. 1938) refusal, as part of her parents' permission for her to act, to never wear sleeveless blouses or swimming suits--and public statements by actresses--for example, the frequently heard insistence of being a simple homebody, indifferent to the glitz and glamor and parties of the film industry, uninterested in romance, unwilling to do "glamour" scenes with kissing and the like--often play up their "traditional" homely qualities, their shyness and family commitment. Such offscreen image-work is undertaken to counter the always already sexist assumptions about an actress and mitigate the insistent presence of her image, attempting to separate and absent her personage from every animating instance of her screen appearance.

\section{$<$ A $>$ Sound-Image}

Presence is not only a visual matter. The pleasures and performative power of images also depend on their aural elements (Taylor). As we will see, vision-image and sound-image work together to create and mitigate the effects of presence in several ways: by doubling startexts, by multiplying presences and absences on and offscreen, and by introducing different possible combinations and circulations of voice, name, and body.

One of the immediately apparent features of the item number "Kalasala Kalasala" is the fact that the actress onscreen and the singer who provides her voice are two different people. As noted earlier, the thin, fair, youthful body of North Indian actress Mallika Sherawat (b. 1976) is paired with the aged voice of the well-known septuagenarian Tamil playback singer L. R. Eswari (b. 1939). With relatively little attempt to synchronize body and voice in a "realistic" manner, this pairing exposes the artifice of visual-aural synchronization as just that: artifice. But this is not a technical slip-up; rather, it points to an established division of aesthetic labor between 
acting and singing that has been a general feature of popular Indian cinema industries since the 1950s. While the use of singing actors and actresses had been prevalent in the 1930s and 1940s, this gave way to a system that would come to be called "playback": the recording of singers' voices first in the studio and their "playback" on the set to be lip-synched by actors and actresses in song sequences. ${ }^{14}$ Playback generates a system in which participant roles are multiplied, a fact that in turn has important implications for the creation and management of presence.

Playback's acknowledgment of the multiple persons involved in producing the figure on screen stands in contrast to a key preoccupation of Hollywood cinema: achieving a unity of body and voice, representing them as springing from the same source, despite (or rather because of) their disarticulatability by technical means. Doane writes: "Classical mise-en-scène has a stake in perpetuating the image of unity and identity sustained by this body and in staving off the fear of fragmentation. The different sensory elements work in collusion and this work denies the material heterogeneity of the 'body' of the film" ("Voice" 47$).{ }^{15}$

In Tamil cinema, this "material heterogeneity" is not only acknowledged but valued. The default condition is that appearance and voice do not have the same indexical source, and there is no need to hide this because they are known and expected by the audience not to. As we can see in "Kalasala Kalasala," the difference between the appearing actress and the playback singer who voices her is part of the spectacle's pleasure. Besides fragmenting the female form, this specialization of roles also multiplies potential presences and absences; in addition to multiple offscreen "authors" (music directors, lyricists, scriptwriters), there are multiple onscreen “animators" (actors/actresses, playback singers, dubbing and Foley artists) (Goffman). A key implication of this for song sequences is that it places two animators (and their associated star- 
texts) in juxtaposition: that of the actress whose body "animates" the song visually and that of the singer whose voice "animates" the song's words and melody.

In "Kalasala Kalasala," it is thus not only the actress Mallika Sherawat who appears as herself, but also L. R. Eswari, the singer. The film, through the prominent special credits given to Eswari, and the trailer, which shows juxtaposed shots of Eswari singing in the studio with scenes of the filming of Mallika's dance, both make sure that viewers know not only who is appearing onscreen but also who is singing, for these are acts that have far-ranging implications beyond, rather than simply in relation to, the film's diegetic world.

Film theory has made space for the consideration of "disembodied" voices through the concept of the acousmêtre, the voice delinked from an onscreen image of a body producing it (Chion). The idea that power relations are generated through the opposition between onscreen synchronized voices and offscreen acousmatic voices is elaborated in Silverman's now classic work, The Acoustic Mirror. Elaborating Mulvey's insights about the visual image and the objectification of the female body, Silverman argues that this objectification turns on the difference between, and hierarchical positioning of, voice as being and voice as discursive agent (44). In the terms of this critique, Hollywood films pit the disembodied male voice, endowed with omniscience and omnipotence by virtue of not being attached to a visible body, against the synchronized, and thus embodied, female voice. Up to this point, basic observations about the sociology of Tamil film production certainly support the gender critique made by Silverman: after all, music directors, lyricists, and directors, who are arguably in the position of "discursive mastery," are overwhelmingly male; and, as we have noted, it is now rare for heroines to provide their own voices for their characters. Read from the point of view of the film as representational 
text where the author is paramount, it would certainly seem that women (both actresses and singers) are denied authorship and confined to the role of animator.

Silverman goes on to argue that while the male subject is identified with a transcendental and omniscient auditory and speaking position, the female subject is persistently confined to the interior of the diegesis. This is accomplished, Silverman suggests, by being made to speak or vocalize involuntarily within the story, and by giving female voices some feature, such as an accent or a low husky timbre, that identify them with "intractable materiality" (57-61). Again, this seems to pertain to "Kalasala Kalasala." Eswari's voice is widely described by Tamil film producers and viewers as particularly suited to conveying female sexual desire and was used throughout the 1960s and 1970s as the singing voice for female characters who were in various ways outside the bounds of respectability (Weidman, "Remarkable"). In "Kalasala Kalasala," it is not only the timbre of Eswari's voice but also various stylistic elements that identify her voice with an "intractable materiality." Her crisp articulation, with its pronounced "ch" (alveolo-palatal

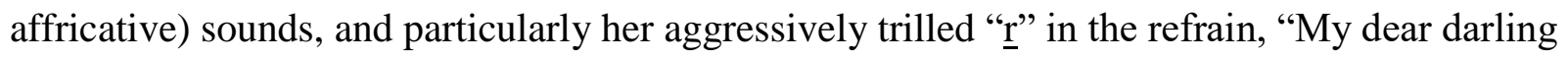
unnai Mallika kūppițrrrā”, (“My dear darling, Mallika is calling you”), are exaggerated vocal gestures meant to evoke a Tamil "folk" style that draws attention to the lips, mouth, and breath and thus to singing as a physical, bodily act. The heavy trill coincides with the double entendre of kuppitu, to call or issue a come-on, providing a kind of sonic/denotational icon of the looseness of Mallika's, and Eswari's, character. ${ }^{16}$ The heavy breathing sound that comes midway through the song, implied to have been made by Eswari, can be taken as an example of the female voice being made to utter the kind of "involuntary" vocalizations (sighs, groans, screams, and so on) that Silverman cites as devices that confine the female voice to pure "being."17 
Yet in the Tamil context, the salient opposite of this embodied, sexualized voice is not the disembodied, authoritative discursively masterful male voice posited by this line of theorizing. Rather, the salient opposite would be the clear, "chaste" voice of Eswari's contemporary, the playback singer P. Susheela (b. 1935), who provided the singing voice for the "good" female characters of Tamil cinema during the 1960s, the heyday of their careers. Although Eswari's and Susheela's voices inhabited the same pitch range, the timbral and stylistic contrast between their voices (developed through constant juxtaposition in films) worked to consistently identify Eswari's with sexualized bodily performance and desire, while Susheela's voice was conceived of, by herself and others, as independent of bodily involvement.

The main dynamic here thus does not revolve around discursive mastery and its opposite, and this is because the stakes are different. For rather than upholding the integrity of the diegesis, actress and singer are, quite independent of the diegesis, engaged in the risky play of presencing themselves through the screen. Contrary to what Silverman argues, here the presencing of the singer's (and the actress's) body works not to fold her into the "inner" space of the diegesis, but instead to remove her from it, to draw attention to her offscreen persona as the kind of singer or actress who would perform such an act. According to this semiotic ideology, Mallika the actress and Eswari the singer are indeed a good "match," not because they convincingly create the illusion of a unified body onscreen, but because they are understood, even across considerable ethnolinguistic and age gaps, to be the same type of woman offscreen: the type who would be willing to use their body/voice to animate the spectacle of a sexualized performance. ${ }^{18}$

But this spectacle is hardly the occasion for uninterrupted voyeuristic pleasure. The mismatch between the body onscreen and the voice that is heard breaks any voyeuristic illusion of peering/overhearing as if from behind a fourth wall. Instead, the viewer is confronted with the 
artifice of the combination of body and voice, both of which, rather than interacting with and supporting each other (what Rick Altman calls "reinforcing each other's lie" [70]), are addressing the viewer frontally, directly.

While the frontal presentation of Mallika is accomplished through her winks to the viewer and "looks" at the audience, and through her naming in the song's refrain, its counterpart, the frontal presentation of the singer to the viewer, must be accomplished through another device: the singer's interdiscursive reference to her own singing persona across many different films. Eswari's performance of the heavily trilled "re," her unabashedly "husky" timbre, and the raunchy lyrics that she is willing to sing, are all telltale signs that make reference to Eswari's songs from earlier decades and to her well-known persona as a "vampy" singer. ${ }^{19}$

The direct, frontal presentation of the singer is also accomplished by the incongruence of the vision-image's and the sound-image's qualia of frontality. In sound recording and sound studies, directness has been primarily conceived as being produced through the effect of closeness (Doyle), the lack of reverb that makes the sound seem "dry" and contained by a small space. In "Kalasala Kalasala," however, one of the most immediately striking features is its use of pronounced reverb for all the voices, especially Eswari's, which seems to create a large and distant aural space distinct from that constructed by the visual close-ups and direct looks of Mallika. Auto-Tune effects on Eswari's voice add to this, lending her voice in parts a soft, shadowy, and even more distant quality; it is anything but "in your ear" the way Mallika's body is "in your face." With this production design, even if the voice did more "believably" match Mallika's character/body, it couldn't possibly be coming from her. And this is the point. The singer is presented as herself, but the production of the voice keeps it at a distance, not only from Mallika and the visual spectacle more generally but from the audience as well. 
The seeming independence of the sound track here seems to support film sound theorists' contention that the sound track, far from being always in service of the visual track, often "wanders" in its own way (Altman 74). Unlike in narrative parts where sound is used to "anchor" the image, it is particularly in the creation of "spectacle" that nonsynchronous sound dominates. Williams has noted that while nonsynchronous sound has been theorized by Silverman and others in relation to its potential to "deconstruct the dominance of the image, especially the patriarchal, fetishized image of women" (122), it can also be used to create "aural fetishes" that shore up viewers' pleasure and fantasy, as in hard-core film and video. In such cases, however, the fetish-character of sound comes from its seeming closeness and intimacy, its "object"-ness (Metz and Gurrieri), as well as from the anonymity of its source. But none of these apply to Eswari's voice. For as we have seen, her voice is not positioned as "close" to the listener at all, and it is anything but anonymous or detached from her body. If it is neither acting as a closely heard vocal fetish, nor serving to shore up the viewer's identification with and recognition of the star, what, then, is this voice doing?

To address these questions, we need to move beyond the plane of text-diegesisrepresentation to figure out what kind of act singing constitutes. What is the social apparatus at play here that "orders" voices (Bonitzer 332), particularly singing voices, regimenting their meaning and their potential effects?

\section{$<\mathrm{A}>$ "Just the Voice"}

Let us return to an obvious but important aspect of playback: the singer is not the actress. Inhering in this simple division of labor is a more categorical distinction: the singer is not an 
actress. The opposition between singing and acting in South India is a charged contrast that dates from late nineteenth-century social reform and "revival" of the "classical" arts of music and dance, for it was under the sway of these projects that singing and acting came to be categorized in terms of their differing respectability (Weidman, Singing). Performance genres that required a great deal of bodily movement were relegated to the "low" cultural realm, while modes of performance in which the performer engaged in little physical movement came to be considered as art. While the early decades of Tamil cinema featured singing actors and actresses whose status was protected by the assumed moral rectitude of singing, by the late 1940s singing and acting were increasingly defined as separate activities, their practitioners placed on opposite ends of a moral divide between good "family women" who maintained a modest physical presence in public and women of questionable moral standing who displayed their bodies for all to see.

Female playback singers, inheriting these categorizations, conceived of themselves as "just the voice"--a conduit-like status constituted through multiple oppositions: just the voice and not the body; just singing and not acting; just singing and not authoring or "meaning" the words. For female singers of Susheela's generation, live appearances and performances constituted a crucial form of offscreen work: presenting themselves as separate and different from the characters and actresses for whom they sang. The respectable norm in live stage performances was for the singer to stand stock still before the microphone while singing, gaze fixed not on the audience but on the music stand, using one hand to keep the end of her silk sari carefully draped over her right shoulder in a standardized sign of sartorial modesty. Furthermore, from the 1950 to the 1980 s, despite the fact that many songs were composed only in skeletal form before being given to the singer to realize more fully, female playback singers assiduously denied their involvement in composing songs or authoring lyrics, presenting themselves as merely a 
reproductive technology for "playing back" songs that had been written by others. And although since the 2000s some male actors have started to write and sing their own songs, collapsing the roles of actor, singer, music director, and lyricist, it is still uncommon for an actress to sing her own songs.

\section{$<$ A $>$ Voice, Name, Body}

What is at stake in maintaining this role of "just singing" (not dancing, acting, authoring, or speaking)? Doubly constituted by the idea that the singer's work is reproductive (merely giving voice to something authored by others) and specialized (only singing, not acting or speaking), singing here is framed as a positively valued act because it does not involve the singer's body as acting does, or the singer's self/will/intention as speaking does. Staying within the "singing" frame is what allows a female singer to be named/known, and to present her “self"/body in live appearances without presencing herself in ways that would compromise her respectability. The fragmentation of the female body and voice--its co-animation by actress, singer, and dubbing artist--is thus a way of separating out body, singing voice, and speaking voice to reduce the intensity of performative presencing onscreen.

To be presenced as a singer means not simply that people know whose voice it is--that is, that the voice is biographically grounded in the singer's name--but that the voice and name become biographically embodied: connected with the singer's body, will, and intention. This biographical embodiment, an element of the presencing of the body, does not depend on one's visibility/appearance on the screen or stage; a playback singer's body may be presenced when all we hear is her voice singing or disavowed when she is performing on stage. ${ }^{20}$ 
Managing this potential presencing and preserving the singing frame requires further distinctions to be upheld, and for female singers of Susheela and Eswari's generation, prime among these was the distinction between "singing" and "effects": those moments when there was some kind of voiced emotion or bodily reaction. Unlike merely singing about (that is, representing) an emotion or feeling, performing "effects" necessitated producing the sound of that emotion/feeling--an iconic representation of it--therefore introducing the possibility, for audiences and singers, that the playback singer was indeed feeling it herself. While male singers sometimes performed laughing or heightened speech effects in songs, the variety of possible effects was greater for female singers and performing them had more extensive ramifications for the star texts and reputations of female singers.

The category of "effects" came into the vocabulary of singers, music directors, and listeners soon after playback singing became established in the 1950s as a way of maintaining the separation between these moments in songs and the act of singing, and also asserting a distance between the singer's self and the screen and diegesis. A wide range of vocalizations came to be categorized as "effects," including those closer to denotational language, such as using English words, speaking dialogue, folk pronunciation (for example, the trilled " $\underline{\text { ") }}$, or heightened speech; a middle range of relatively common stylized vocalized emotions, such as crying, sighing, or laughing; and at the further end, nonverbal, nonmusical vocalizations such as hiccupping, swooning in delight or pain, or heavy breathing, which were less common and therefore less stylized.

Even while performing them, the singer's self was distanced from these effects in several ways. Effects were sometimes preceded by a pause or full stop between the singing voice and the effect. Stylization also performed a shielding function, making the sigh, laugh, or cry more a 
citation of emotion than a spontaneous expression of it. And the very conceptualization of these moments as effects conjured the image of a Foley artist manipulating objects before a microphone to trick the ears of listeners rather than that of an engaged performer authentically portraying an emotion.

Despite these varied ways of containing the potential excess of these effects, managing their performative force was challenging, and performing them was always a liability for female singers. This was not only because effects came perilously close to acting but also because they admitted the intimate presence of the body in the sound itself. Effects were an extension of the breathy or what would come to be called the "husky" voice, associated with available female sexuality and the expression of female desire. The potential performativity of effects implicated not only listeners' perception and emotions but also the singer's own moral character, and it thereby affected the kinds of screen worlds she could inhabit. Permanently marking the singer and sticking to her voice, performing such effects could make her unsuited for singing other kinds of songs in which emotion and desire are licitly cloaked by "melody" or themes of "love" or "classical"-ness (all named genres, along with the item number, in Tamil cinema). ${ }^{21}$

If huskiness could be produced by adding the slightest hint of breathiness to a voice, the logical culmination of this--the crystallization of a particular vocal timbre into an effect--is pure breath without the voice at all. This brings us back to the heavy breathing moment in "Kalasala Kalasala." Entirely different in quality from the rest of the song, its seeming nearness contrasts with the reverberant singing voices. The heavy breathing sound here is not even acknowledged as an effect, but rather blends ambiguously with the song's soundtrack, mistakable for some sort of synthesized percussion sound. Onscreen, there is no visual cue linking the sound to Mallika. Nor is there any offscreen crediting of this portion of the song to Eswari in the two-minute 
"making-of" video, which cuts from a scene of Eswari singing early on to Mallika on the set to the male singer and yesteryear hero T. Rajendar (b. 1955) singing in the studio, and then to the scene of Osthi/Simbu dancing on the set while the heavy breathing is going on. We only see Eswari singing again toward the end of the video, well past the heavy breathing moment.

Both the sonic ambiguity of this moment and its lack of grounding in the visual mise-enscène are striking. But neither is accidental. They are carefully constructed moments, like many others in Tamil cinema, where visibility and audibility are managed, where the female body and voice are alternately presenced and withdrawn, put on display and sequestered from their surrounds. We see the hypervisible body of Mallika but hear neither her singing nor her speaking voice. By contrast, we hear the heavy breathing, though we are not sure who is producing it or even if it is coming from a human source. At the very moment that the voice at its most bodily is made intimately audible, its source is occluded, rendering it almost, but importantly not quite, anonymous.

\section{$<$ Ill $>$}

As we have argued, in Tamil cinema, body and voice, appearance and audition, acting and singing, sight and sound, are organized around a dialectic of representation and performativity. While the former casts the profilmic act of acting or singing as simply contributing to a diegetic narrative, the latter highlights the presence of the film image; it construes acting and singing as acts that not only have been captured by the recording apparatus but are shown to a public. Such acts have implications for the reputation of the person who performed them. The representational mode shields the actress' or singer's offscreen identity and 
persona by having her stand under the authorizing role of someone or something else, such that she can be seen as just portraying a character in a story or as "just the voice." By contrast, the performative mode presences the actress's or singer's offscreen persona and identity, making the song and the performance of it palpably return to her herself instead of, or in addition to, the onscreen character, diegetic situation, or their author(s).

These "modes" are not discrete types of images; filmic images are, after all, always both representations and acts. Rather, these modes are tendencies or potentials whose differential play we can discern in certain symptomatic cinematic sites where the "act"-ness of an image is emphasized over its status as a representation. In Tamil cinema, female sexuality is such a site, one that renders these two modes maximally distinct. This is because the film image enables forms of presence that are problematic within a patriarchal economy of public appearance in Tamil Nadu. Indeed, while there are definite differences among ways of appearing publicly (on the street, at the market, on the theatrical stage, on television, on social media, and so on), these exist on a continuum within which, as we have suggested, cinema presents the problem of presence most acutely. What makes this so is the fact that, among other reasons, cinematic images in Tamil Nadu are not just indexical traces from the past in the present but acts in a continual present, tethered to the moment of public consumption and its further embodied and discursive entailments (for example, titillation, stigma, gossip, and so on).

Certain labors, on and off the screen, must be undertaken to mitigate the risks of such presence, even--or perhaps especially--in a highly sexualized item number like "Kalasala Kalasala." These labors range from the fragmenting of the female figure into body, singing voice, and speaking voice--and the strategic (mis)matching of these elements--to the veiling of female presence by the diegesis, to the offscreen image work done by actresses and female 
singers (and audiences) to distance their selves from what goes on onscreen. The division of semiotic labor between appearing and sounding means that actresses are de-voiced and singers dis-appeared, though this is never total. Rather, this division is itself part of a mediatized economy of (il)licitness that revolves around exchanges between what is heard and what is seen, what is absented and what is presenced. In Tamil cinema, hierarchies of relative respectability have traditionally placed singing over acting and hearing over seeing, using the moral licitness of a woman singing to mitigate the assumed immorality of a woman acting.

The chronological spread of our examples, ranging from the 1960s to the 2010s, is not meant to suggest that things have remained the same for women in Tamil cinema or that the aural and the visual have interacted in the same ways throughout this period. Important shifts have taken place in the last fifty years that have affected the relative status of actresses and female playback singers, and of acting and singing more generally. The song sequence "Kalasala Kalasala" itself seems to reflexively comment on this history by oscillating between the incongruous juxtaposition and uncanny conflation of a current "item" actress and an elderly playback singer.

In the 1950s and 1960s, actresses in Tamil cinema gave voice to their own dialogues. ${ }^{22}$ Their capacity to use their own speaking voices coincided with--and indeed was dependent on, we argue--the dominance of the figure of the "respectable" female playback singer (exemplified by a singer like P. Susheela), who provided actresses with a singing voice that maintained the conditions of the singing frame. The moral licitness of the respectable singer (itself contingent on how and what she sang) worked to lift the status of the actress, as evidenced by various stories in the industry of actresses in the 1960s "longing" to be allowed to sing, or of the "dignity" bestowed on actresses by the singing voices of "respectable" singers like Susheela (also see 
Sundar). At the same time, the concentration and containment of immoral singing during this period in a foil figure like Eswari worked to guarantee the respectable status of singers like Susheela and of "singing" itself. This fractally recursive distinction (Irvine and Gal) along lines of respectability was also found in the relatively rigid division among actresses between heroines and vamps.

This structural arrangement--the dominance of a few respectable singers and actresses and their vampy foils--began to break down in the 1970s. It has given way, since the 1990s, to a competitive field with many more singers with new and different vocal sounds and styles, including breathy timbres, grunts, and other elements that would not have been allowable within the singing frame in earlier decades (Weidman, "Neoliberal"). While it is often argued that this expansion, linked with assertions of vocal modernity and cosmopolitanism (and decreasing stigma attached to cinema), has afforded female singers more creativity and freedom to sound different, this breaching of the singing frame has also arguably lowered the celebrity status of singers and of singing more generally. ${ }^{23}$ And the increased number of singers has resulted in a condition in which singers' careers are relatively ephemeral; they are often unable to get enough songs to achieve the kind of voice recognizability that singers of earlier decades enjoyed. Relatively less known, many sing under conditions of partial anonymity, which carries its own risks.

Along with, and indeed related to, these changes in the status of singers are a host of parallel changes in the fates of actresses: the shift to using dubbing rather than sync sound for all dialogues in the 1970s and 1980s; the breakdown of the vamp-heroine distinction, the sexualization of the heroine character, and her decreased importance to the narrative in the 1990s (Chinniah); changing norms of onscreen and offscreen appearance; the growing number and 
diminished career-lengths of heroines, who have since the 1990s increasingly not only come from non-Tamil backgrounds but often cannot speak or act in Tamil well enough to dub their own voices (Karupiah; Nakassis, "Tamil-speaking”); as well as an expansion of the kinds of heroines' speaking voices heard onscreen (for example, lower in pitch, more "natural," rougher).

These historical changes are linked. With the economies of respectability anchored in playback singing less able to counterweight the stigma of the screen, the voice and body of the singer and actresses have destabilized earlier filmic regimes, rendering precarious the fates of both singer and actress. Item numbers, emerging in the postliberalization period, represent the logical culmination of these changes, featuring devoiced and denarrativized figures of alterity, sequestered and sexualized in stand-alone sequences that exceed the representational frame, leaving the singer's and dancer's presence bare on eye and ear.

And although item numbers are a postliberalization phenomenon, they crystallize and amplify gender and textual dynamics that have a provenance as old as the regional Indian cinemas themselves: the acknowledgment of the performative character of film images and the accordingly careful handling of the female figure, and the alternation and tension between representational narrative and the presencing of actors, actresses, and singers as themselves.

This dynamic is not particular to Tamil or Indian cinemas; rather, it is at play in all cinematic images. All cinematic images are potentially performative acts. ${ }^{24} \mathrm{We}$ need only think of criticisms of European and American directors for the politics of their films (for example, the alleged anti-Semitism of Mel Gibson's Passion of the Christ) or for their sexually "explicit" and violent depictions and treatment of actresses (for example, Bernardo Bertolucci's Last Tango in Paris), or of actresses' performances and performance choices (as with, for example, Chloë 
Sevigny in The Brown Bunny). Even more recently, we might think of the discussion linking onscreen portrayals of women and their offscreen treatment in Hollywood that has arisen since the recent public "revelation" of producer Harvey Weinstein's sexual harassment of actresses (the effects of which have reverberated in Indian film industries as well). ${ }^{25}$

With the acknowledgment that all cinematic images are potentially performative acts, the questions become: How is such performativity cultivated or mitigated? To whom are such acts attributed and to whom are they understood to be addressed? To what ends, with what effects, and in whose interests? And in what ways and to what extent does the film image itself register this performative potential and take it on as its animating force? If classic Hollywood cinema has selectively disavowed its performativity (figuring its images as not acts), Tamil cinema reflexively amplifies its performativity, curating and dispersing the presences it affords through appearances and sounds in a complex semiotic economy, on and off the screen. Our goal here is not to draw hard lines between types of images or cinematic traditions, but rather to attend to the dynamic processes and potentials of presencing and representation that manifest in and as images, processes and potentials that may be selectively elaborated and institutionalized or played down and attacked, always in historically and culturally specific ways and for/by particular interests. Attending to these dynamics is critical for theorizing cinema not only as a textual phenomenon but also--as feminist film theory has long argued--as a political object and object of politics whose implications extend far beyond the film text, the set, and the theater.

\section{$<$ Begin ack>}


This paper emerged out of a set of conversations between the authors at the annual Chicago Tamil Forum workshop where early versions of these arguments were presented and discussed. We thank the other participants at the workshops for feedback, as well as the helpful comments from two critically engaged peer-reviewers. Both authors have contributed equally to this article.

\section{$<$ End ack>}

\section{$<$ Begin cn>}

$<\mathbf{s c}>$ constantine v. nakassis $</ \mathbf{s c}>$ is an assistant professor of anthropology at the University of Chicago. He is the author of Doing Style: Youth and Mass Mediation in South India (University of Chicago Press, 2016) and is currently working on a book manuscript on Tamil cinema titled, Onscreen/Offscreen.

\section{$<$ End cn >}

\section{$<$ Begin cn>}

$<\mathbf{s c}>$ amanda weidman $</ \mathbf{s c}>$ is an associate professor of anthropology at Bryn Mawr College. She is the author of Singing the Classical, Voicing the Modern: The Postcolonial Politics of Music in South India (Duke University Press, 2006) and is currently working on a book on the affective politics of playback singing in Tamil cinema.

\section{$<$ End cn $>$}




\section{$<\mathrm{A}>$ Notes}

1 For us, an image is not necessarily visual but includes iconic forms in any modality; see Mitchell 16-18.

2 See Hoek on similar dynamics in Bangladeshi cinema.

3 Metz, Imaginary; for contrasting arguments on spectatorship, see Doane, "Film"; Gledhill; Stewart; and Willemen.

4 "Semiotic ideology" here denotes presuppositions about signs (including but not limited to language and mass media) that dialectically guide engagement with, interpretation of, and even production of the semiotic phenomena they rationalize and construe. See Irvine and Gal; and Keane.

5 The performativity of the image qua act has been central to Western academic debates about the pornographic image. See, for example, MacKinnon; and Williams. Our suggestion here is not that the image-acts under consideration in this paper (or by authors like MacKinnon) are inherently performative; rather, we ask, under what conditions might they come to be performative, with what political entailments and presuppositions, and with what frailties and vulnerabilities to being defeased?

6 See Metz, “Impersonal” for an argument disputing Casetti’s deictic theory of filmic enunciation.

7 While sexualized dance sequences have a long history in Indian cinemas, the item number as such emerged in the 1990s after the liberalization of the Indian economy. The 1990s saw the 
corporatization and globalization of Hindi cinema, a process that resulted in the reorganization of addressivity of such films to elite "A-center" multiplex and diasporic audiences. As S. V. Srinivas has recently suggested, this opened up new possibilities for regional cinemas such as Tamil cinema to address working-class audiences in other regions, something that turned on increased "below-the-line" costs that packed in "attractions": in addition to celebrity heroes, such films increasingly featured spectacular special effects, fight scenes, foreign locales, big-name non-Tamil heroines, and well-known technicians. This period also saw the rise in satellite television access (filled with film content), home-viewing, and piracy $(\langle\mathbf{s c}\rangle$ vhs $</ \mathbf{s c}\rangle$, then $\langle\mathbf{s c}\rangle \mathrm{vcd}\langle/ \mathbf{s c}\rangle,\langle\mathbf{s c}\rangle \mathrm{dvd}\langle/ \mathbf{s c}\rangle$, and now online), a shift in the mediascape that kept the "family audience" (that is, women and children) away from theaters. The result was a (perceived) increase in young male viewers as the major (first-week) audience. It is in this period that item numbers emerged, along with the increased sexualization of the heroine (and her merger with the "vamp"; indeed, many item numbers came to be danced by heroines), and her decreased importance to the narrative (as "sentiment" scenes were on the wane in this increasingly masculinist cinema).

8 As Ganti has suggested in her work on Hindi cinema (80), and as is confirmed by Costas's research on Tamil cinema, item numbers are viewed by filmmakers and audiences as crass and commercially driven, titillating sequences that interrupt the story (Gopalan); the value of a director is often measured by his ability to reintegrate (if he cannot simply avoid) the item into the narrative.

9 The camera doesn't just linger on Mallika's body and face. It also builds her up, according her a tropology that is often reserved for Tamil film heroes. Consider, for example, the way in which (around three minutes into the song) her body is multiplied in triplicate on the screen, a trope of 
bigness and importance that is typically reserved for the largest, most massive of hero-stars. See Nakassis, Doing 188-223.

10 This fourth look is constituted precisely as the look of the image/actress itself/herself as she, presenced, constitutes the viewer as her inter-subject/object of vision.

11 As feminist work in South Asian studies has suggested, for women, representation in the public sphere has long posed the problem of how to manage presence. For example, Mrinalini Sinha has examined the strategies used to construct an Indian middle-class feminist "voice" in the late 1920s that would be considered appropriately respectable while also managing to be heard as authoritatively "political." A number of essays have also examined issues of representation, agency, and the problematics of presence and performativity in representations of Phoolan Devi, through film, autobiographical narrative, and in public appearances by Phoolan Devi herself (see Fernandes; Murty; Sunder Rajan). The controversy around the film Bandit Queen (1995, dir. Shekhar Kapur), particularly the much discussed scenes of violence and rape, suggests that attempts to control film as a narrative representation are always liable to be disrupted by the performativity of the filmic image.

12 See Seizer's ethnographic discussion of stigma management in popular Tamil theater.

13 While many actresses simply retire and disappear from the screen after marriage, some move on to serials or other kinds of female-oriented programming on the small screen. Televised images are often construed as less stigmatizing for women. This is linked to the genres that dominate television (serials that feature family dramas) and the reception contexts (television is contained within the home and often watched by families all together), as well as to widespread 
beliefs about the television industry as "just work," as a form of media production that allows for no downtime on set to make "mistakes."

14 On "song dubbing" in Hollywood musicals from the 1930s to the 1960s, see Siefert.

15 Sound, according to this conception, works to suture together fragments so as to reassure the spectator. According to psychoanalytic readings, the soundtrack acts as a kind of "sonorous envelope" that helps to shore up the spectators' sense of the unity of him/herself and the film alike. See Baudry; Bonitzer; and Chion, Voice.

16 Indeed, the autoreferential use of the personal name "Mallika" at the beginning of the song ("My dear darling, Mallika is calling you") is ambiguous between two different production formats that are simultaneously at play (Goffman): the words as animated by Mallika ("I, Mallika am calling you") and as animated by Eswari (“She, Mallika is calling you”). The words are mouthed by/seen as Mallika but voiced by/heard as Eswari, just as Eswari and Mallika are simultaneously equated and differentiated in this song.

17 Also see Greene; and Lawrence.

18 In this one way, Mallika and Eswari are the same type of woman, though the ethnolinguistic gap between them is a crucial difference that is an important part of the construction of the spectacle. As Nakassis has argued ("Tamil-speaking"), within the context of cultural and language politics in Tamil Nadu, the contemporary Tamil-speaking heroine has been constructed as an impossible figure. Those women who do appear onscreen (a class of actresses that includes heroines and of whom the item-girl is simply a more extreme case) are rendered mute by virtue of their inability to speak Tamil (and by virtue of the normative fiat that no authentically Tamil 
woman would appear onscreen), thus necessitating dubbed speaking and singing voices that can perform in Tamil. Mallika, by virtue of her foreignness, is a "sight-able" actress because she is figured as unrelated. But in turn, what is being foregrounded and played up in "Kalasala Kalasala" is precisely Eswari's Tamilness--her facility and daring with the language that stems from being ethnolinguistically Tamil (in contrast to her contemporaries Susheela and Janaki who sang for "good" girls and who were both ethnolinguistically Telugu). As Nakassis suggests, the flip side of femininity's appearance onscreen as a "mute foreign body" is its being "heard offscreen as a disembodied Tamil voice [...] who is 'ours' and therefore publicly invisible" ("Tamil-speaking" 173). However, Eswari’s is emphatically not a "respectable" Tamil voice, given her location as a lower-caste woman from a poor background (see Weidman, "Remarkable"); therefore, she must be, through various techniques of cinematic representation, held at a distance, presented as not quite "ours."

19 Such interdiscursivity is at issue in the presencing of heroines as well. On the interdiscursivity of Tamil heroes, see Nakassis, Doing 188-223.

20 On a similar dynamic in Bollywood cinema, see Sundar's discussion of the "bodiliness" of Ila Arun's voice.

21 This is not to say that such effects don't afford their own pleasures, even for the singer. In an interview with the press after the release of the song, Eswari recounted her experience recording the song, including the pleasure others took in hearing her perform this vocal effect: "Everyone wanted me to sing that part "Mallika kūppițrrrrā" again and again” (“L. R. Easwari”).

22 With the advent of sound cinema, Tamil cinema mainly used sync sound up until the 1970s and transitioned into dubbing for dialogues in the 1970s and 1980s. 
23 Coinciding with these changes in vocal sound is a change in the relationship between singers and actresses: rather than disavowing the actress/screen/diegesis, young female playback singers now often identify their selves with the characters for whom they sing in live performance, borrowing some of the actresses' glamour for themselves.

24 Indeed, feminist critiques of classical Hollywood cinema are predicated on the fact that its image is a patriarchal act; but if so, for such theorists, this is because the image is a representation. But as we have argued, it isn't solely the representational qualities of the image that enable it to act. There are other aspects of the image--its materiality, its interdiscursivity, its presence, appearance, sound, and so on--that enable its performativity. Attending to these aspects leads us to a different set of processes and concerns, far beyond the text and its representational surface.

25 Nor, as we have noted, is the performativity of the cinematic image limited to the ways its effects return to the persons of directors or actors/actresses. It also extends to viewers and critics. Consider, for example, the fears that some have expressed in light of recently revived accusations about Woody Allen's sexual affairs, namely, that continuing to watch his films would constitute a morally unsound act (see Scott).

\section{$<\mathrm{A}>$ Works Cited}

Altman, Rick. “Moving Lips: Cinema as Ventriloquism.” Yale French Studies 60 (1980): 67-79.

Baudry, Jean-Louis. “Ideological Effects of the Basic Cinematic Apparatus.” Rosen 286-98. 
Bandit Queen. Dir. Shekhar Kapur. Kaleidoscope Entertainment. 1995.

Bazin, André. “The Ontology of the Photographic Image.” What Is Cinema? Vol. 1. Trans. Hugh Gray. Berkeley: $\langle\mathbf{s c}>\mathbf{u}</ \mathbf{s c}>$ of California $\langle\mathbf{s c}>$ p $</ \mathbf{s c}>, 2004.9-16$.

Bonitzer, Pascal. "The Silences of the Voice." Rosen 319-34.

Casetti, Francesco. "Face to Face." The Film Spectator: From Sign to Mind. Ed. W. Buckland. Amsterdam: Amsterdam <sc >up</sc >, 1995. 118-39.

Chinniah, Sathiavathi. "The Tamil Film Heroine: From a Passive Subject to a Pleasurable Object." Tamil Cinema: The Cultural Politics of India's Other Film Industry. Ed. Selvaraj Velayutham. New York: Routledge, 2008. 40-41.

Chion, Michel. Audio Vision: Sound on Screen. Ed. and trans. Claudia Gorbman. New York: Columbia $<$ sc $>$ up $</$ sc $>, 1994$.

----. The Voice in Cinema. Trans. Claudia Gorbman. New York: Columbia $<\mathbf{s c}>$ up</sc>, 1999.

Doane, Mary Ann. "Film and the Masquerade: Theorizing the Female Spectator." Screen 23.3-4 (1982): 74-88.

----. "The Voice in Cinema: The Articulation of Body and Space." Yale French Studies 60 (1980): 33-50.

Doyle, Peter. Echo and Reverb: Fabricating Space in Popular Music Recording, 1900-1960. Middletown: Wesleyan $\langle$ sc $>$ up $</$ sc $>, 2005$. 
Fernandes, Leela. “Reading 'India's Bandit Queen': A Trans/national Feminist Perspective on the Discrepancies of Representation.” Signs 25.1 (1999): 123-52.

Ganti, Tejaswini. Bollywood: A Guidebook to Popular Hindi Cinema. New York: Routledge, 2004.

Gledhill, Christine. "Pleasurable Negotiations." Female Spectators: Looking at Film and Television. Ed. E. Deidre Pribram. London: Verso, 1988. 64-89.

Goffman, Erving. "Footing." Forms of Talk. Philadelphia: $\langle\mathbf{s c}>\mathbf{u}</ \mathbf{s c}>$ of Pennsylvania $\langle\mathbf{s c}>\mathrm{p}</ \mathbf{s c}>, 1981.124-57$.

Gopalan, Lalitha. Cinema of Interruptions: Action Genres in Contemporary Indian Cinema. London: $\langle$ sc $>$ bfi $</$ sc $>, 2002$.

Greene, Liz. "Speaking, Singing, Screaming: Controlling the Female Voice in American Cinema." Soundtrack 2.1 (2009): 63-76.

Gunning, Tom. "Cinema of Attractions." Wide Angle 6.2 (1986): 63-70.

Hansen, Miriam. Babel and Babylon: Spectatorship in American Silent Film. Cambridge, $\langle$ sc $>$ ma $</$ sc $>$ : Harvard $\langle$ sc $>$ up $</$ sc $>, 1991$.

Hardgrave, Robert Jr., Essays in the Political Sociology of South India. New Delhi: Manohar, 1993.

Hoek, Lotte. “'More Sexpression, Please!' Screening the Female Voice and Body in the Bangladesh Film Industry.” Aesthetic Formations: Media, Religion, and the Senses. Ed. Birgit Meyer. Basingstok: Palgrave Macmillan, 2009. 71-90. 
Irvine, Judith, and Susan Gal. "Language Ideology and Linguistic Differentiation." Regimes of Language: Ideologies, Polities, and Identities. Ed. Paul V. Kroskrity. Santa Fe: School of American Research, 2000. 35-84.

Karupiah, Premalatha. "Voiceless Heroines: Use of Dubbed Voices in Tamil Movies." Asian Women 33.1 (2017): 73-98.

Keane, Webb. "Semiotics and the Social Analysis of Material Things." Language and Communication 23 (2003): 409-25.

Lawrence, Amy. Echo and Narcissus: Women's Voices in Classical Hollywood Cinema. Berkeley: $\langle$ sc $>$ u $</$ sc $>$ of California $<$ sc $>$ p $</$ sc $>, 1991$.

“L. R. Easwari on Her Career and 'Kalasalla ... '.' IndiaGlitz. YouTube. 8 Mar. 2012. https://www.youtube.com/watch?v=BnWgB8XYIA8.

MacKinnon, Catherine. Only Words. Cambridge, $\langle\mathbf{s c}>$ ma $</$ sc $>$ : Harvard $\langle\mathbf{s c}>$ up</sc $>, 1993$.

“Mallika Sherawat's 'Osthi’ Item Song Cost 1.2 Crores.” Kolly Insider 3 Oct. 2011. http://www.kollyinsider.com/2011/10/mallika-sherawats-osthi-item-song-cost.html.

Metz, Christian. The Imaginary Signifier: Psychoanalysis and the Cinema. Bloomington: Indiana $<$ sc $>$ up $</$ sc $>, 1982$.

----. "The Impersonal Enunciation, or the Site of Film (in the Margin of Recent Works on Enunciation in Cinema).” New Literary History 22.3 (1991): 747-72.

Metz, Christian, and Georgia Gurrieri. “Aural Objects.” Yale French Studies 60 (1980): 24-32. 
Mitchell, W. J. T. Image Science: Iconology, Visual Culture, and Media Aesthetics. Chicago: $\langle$ sc $>$ u $</$ sc $>$ of Chicago $<$ sc $>$ p $</$ sc $>, 2003$.

Mulvey, Laura. "Thoughts on the Young Modern Woman of the 1920s and Feminist Film Theory." Visual 213-30.

----. Visual and Other Pleasures. London: Palgrave MacMillan, 2009.

----. "Visual Pleasure and Narrative Cinema." Visual 14-27.

Murty, Madhavi. 'Reading the Perplexing Figure of the 'Bandit Queen': Interpellation, Resistance, and Opacity." Third Space: A Journal of Feminist Theory and Culture 9.1 (2009). http://journals.sfu.ca/thirdspace/index.php/journal/article/view/157/282.

Nair, Bindu. "Laura Mulvey and Hindi Cinema." Films and Feminism: Essays in Indian Cinema. Ed. Jasbir Jain and Sudha Rai. New Delhi: Rawat, 2002. 52-58.

Nakassis, Constantine V. Doing Style: Youth and Mass Mediation in South India. Chicago: $<$ sc $>$ u $</$ sc $>$ of Chicago $<$ sc $>$ p $</ s c>, 2016$.

----. “A Tamil-speaking Heroine.” Bio-scope 6.2 (2015): 165-86.

Osthi. Dir. Dharani. Balaji Real Media. 2011.

Ramamurthy, Priti. “The Modern Girl in India in the Interwar Years: Interracial Intimacies, International Competition, and Historical Eclipsing." Women's Studies Quarterly 34.1-2 (2006): $197-226$.

Rosen, Philip, ed. Narrative, Apparatus, Ideology. New York: Columbia <sc>up</sc>, 1994. 
Saltz, David. "How to Do Things on Stage." Journal of Aesthetics and Art Criticism 49.1 (1991): $31-45$.

Scott, A. O. “My Woody Allen Problem.” New York Times 31 Jan. 2018.

https://www.nytimes.com/2018/01/31/movies/woody-allen.html.

Seizer, Susan. Stigmas of the Tamil Stage: An Ethnography of Special Drama Artists in South India. Durham: Duke <sc $>$ up</sc $>, 2005$.

Siefert, Marsha. "Image/Music/Voice: Song Dubbing in Hollywood Musicals." Journal of Communication 45.2 (1995): 44-64.

Silverman, Kaja. The Acoustic Mirror: The Female Voice in Psychoanalysis and Cinema. Bloomington: Indiana $<$ sc $>$ up $</$ sc $>, 1988$.

Sinha, Mrinalini. "Gender in the Critiques of Colonialism and Nationalism: Locating the 'Indian Woman." Feminism and History. Ed. Joan Scott. New York: Oxford 〈sc >up</sc>, 1996. 477504.

Soneji, Davesh. Unfinished Gestures: Devadasis, Memory, and Modernity in South India.

Chicago: $\langle$ sc $>$ u $</$ sc $>$ of Chicago $\langle$ sc $>$ p $</$ sc $>, 2012$.

Srinivas, S. V. "Rajinikanth and the 'Regional Blockbuster."' Working Papers of the Chicago

Tamil Forum--Politics of Media, Media of Politics. 15 Dec. 2016.

http://chicagotamilforum.uchicago.edu/working-papers/.

Stewart, Jacqueline. "Negroes Laughing at Themselves? Black Spectatorship and the Performance of Urban Modernity.” Critical Inquiry 29.4 (2003): 650-77. 
Sundar, Pavitra. "Gender, Bawdiness, and Bodily Voices: Bombay Cinema's Audiovisual Contract and the 'Ethnic' Woman." Locating the Voice in Film: Critical Approaches and Global Practices. Ed. Tom Whittaker and Sarah Wright. New York: Oxford $<$ sc $>$ up $</$ sc $>, 2017.63-82$.

Sunder Rajan, Rajeswari. "Outlaw Woman: The Politics of Phoolan Devi's Surrender, 1983.” The Scandal of the State: Women, Law, and Citizenship in Postcolonial India. Durham: Duke $\langle$ sc $>$ up $</$ sc $>, 2003.212-35$.

Taylor, Woodman. "Penetrating Gazes: The Poetics of Sight and Visual Display in Popular Indian Cinema." Contributions to Indian Sociology 36.1-2 (2002): 297-322.

Vardhan, T. Vishnu. "Rethinking Spectator(ship) and (Male) Gaze in the Context of Indian Cinema." Cerebration. http://www.cerebration.org/vishnuvardhan.html (accessed 8 July 2018).

Vasudevan, Ravi. The Melodramatic Public: Film Form and Spectatorship in Indian Cinema. Ranikhet: Permanent Black, 2010.

Weidman, Amanda. "Neoliberal Logics of Voice: Playback Singing and Public Femaleness in South India." Culture, Theory, and Critique 55.2 (2014): 175-93.

----. "The Remarkable Career of L. R. Eswari." Vamping the Stage: Female Voices of Asian Modernities. Ed. Andrew N. Weintraub and Bart Barendregt. Honolulu: $\langle\mathbf{s} \mathbf{c}>\mathrm{u}</ \mathbf{s c}>$ of Hawaii $<\mathbf{s c}>\mathrm{p}</ \mathbf{s c}>$, 2017. 174-91.

----. Singing the Classical, Voicing the Modern: The Postcolonial Politics of Music in South India. Durham: Duke <sc >up</sc>, 2006. 
Willemen, Paul. "The Fourth Look." Looks and Frictions: Essays in Cultural Studies and Film Theory. London: $\langle$ sc $>$ bfi $</ s c>, 1994.99-110$.

Williams, Linda. Hardcore: Power, Pleasure, and the "Frenzy of the Visible." Berkeley: $\langle\mathrm{sc}>\mathrm{u}</ \mathbf{s c}>$ of California $\langle\mathrm{sc}>\mathrm{p}</ \mathbf{s c}>, 1989$. 